\title{
Vertical Axis Wind Turbine Control Strategy
}

Gerald M. McNerney

Prepared by Sandia National Laboratories, Albuquerque, New Mexico 87185

and Liverinore. California 94550 for the United States Departinent

of Energy under Contract DE-ACO4-76DPOD789

Printed August 1981

\section{When printing a copy of any digitized SAND Report, you are required to update the markings to current standards.}


Issued by Sandia National Laboratories, operated for the United States Department of Energy by Sandia Corporation.

NOTICE: This report was prepared as an account of work sponsored by an agency of the United States Government. Neither the United States Government nor any agency thereof. nor any of their employees, nor any of their contractors, subcontractors, or their responsibility for the a proustor owned rights, Reference herein to any specific commercial product, process, privateiy owned rights. Reference herein to any specific commercial product, process, or service by trade name, trademark, manufacturer, or otherwise, does not necessarily constitute or imply its endorsement, recommendation, or favoring by the United States Government, any agency thereof or any of their contractors or subcontractors. The views and opinions Government, any agency thereof or any of their contractors or subcontractors.

Printed in the United States of America Available from

National Technical Information Service U.S. Department of Commerce

5285 Port Royal Road

Springfield, VA 22161

NTIS price codes

Printed copy: $\quad \$ 5.00$

Microfiche copy: $A 01$ 
SAND81-1156

Distribution

Unlimited Release

Category UC-60

Printed August 1981

\title{
Vertical Axis Wind Turbine Control Strategy
}

Gerald M. McNerney

Advanced Energy Project Division 4715

Sandia National Laboratories, Albuquerque, NM 87185

\begin{abstract}
Algorithm control strategy for unattended wind turbine operation at the low wind speed cut-in condition is a potentially important aspect of wind energy production that has thus far not been fully treated in the literature. Early experience in automatic operation of the Sandia 17-m vertical axis research wind turbine (VAWT) has demonstrated the need for a systematic study of control algorithms. To this end, a computer model has been developed that uses actual wind time series and turbine performance data to calculate the power produced by the Sandia 17-m VAWT operating in automatic control. The model has been used to investigate the influence of starting algorithms on annual energy production. The results indicate that, depending on turbine and local wind characteristics, a bad choice of a control algorithm can significantly reduce overall energy production. The model can be used to select control algorithms and threshold parameters that maximize long-term energy production. An attempt has been made to generalize these results from local site and turbine characteristics to obtain general guidelines for control algorithm design.
\end{abstract}




\section{Acknowledgment}

The author extends his appreciation to M. T. Mattison Division 4715, for his help in initiating this study and to W. N. Sullivan, also of Division 4715, for his continued support and helpful ideas in carrying out the necessary work. 


\section{Vertical Axis Wind Turbine Control Strategy}

\section{Introduction}

We have developed a computer model that uses test data to calculate the energy produced by a vertical axis wind turbine (VAWT) running on automatic control. The purpose of the model is twofold:

- To develop guidelines in control algorithm strategies. This task was initially undertaken by using data specific to the Sandia/DOE VAWT and it produced interesting results that could be applied to the automatic control program.

- To provide general information on the percentage of energy available to a VAWT that is lost in the automatic control process. This information will be used to select economical VAWTS for specfic sites.

I will discuss the automatic control model, followed by the algorithms tested and their results, and finally, generalized information that will apply to other turbine-site pairs. *

\section{The Computer Model}

The computer model was designed to simulate the Sandia/DOE 17-m Research VAWT at Albuquerque, NM, running on automatic control. Two sets of data are needed to simulate a turbine-site pair:

- A turbine electric power curve (EPC) that presents the turbine's power output as a function of windspeed

- A windspeed-time series at a sampling frequency of at least $0.1 \mathrm{~Hz}$

*A turbine-site pair refers to a site and a turbine considered as a unit; some turbines may not be compatible with a particular site, but only by combining the specifications for both can compatibility be determined.
The EPC data is a set of Bins data collected at the Sandia test site from the 17-m VAWT, operating at $5.3 \mathrm{rad} / \mathrm{s} .^{1}$ Figure 1 plots these data. The windspeedtime series data were collected in 43 recording periods totalling 890 hours (at a frequency of $0.5 \mathrm{~Hz}$ ) during weekends and nights of the summer and fall of 1979 . The probability density function of the windspeed is plotted in Figure 2. The mean value of windspeed for the data is $4.96 \mathrm{~m} / \mathrm{s}$, which is above the actual Albuquerque mean annual windspeed, thereby reflecting a bias toward high wind.

The computer model itself is a FORTRAN program in which the electric power, as a function of windspeed data, is used to determine the power available at each sampling event. If the turbine is stopped, the control algorithm uses the power available to decide if the turbine should be started. If the turbine is running, the power is summed to determine the energy generated. (I will be discussing portions of the more interesting control algorithms in FORTRAN logic later in this report.)

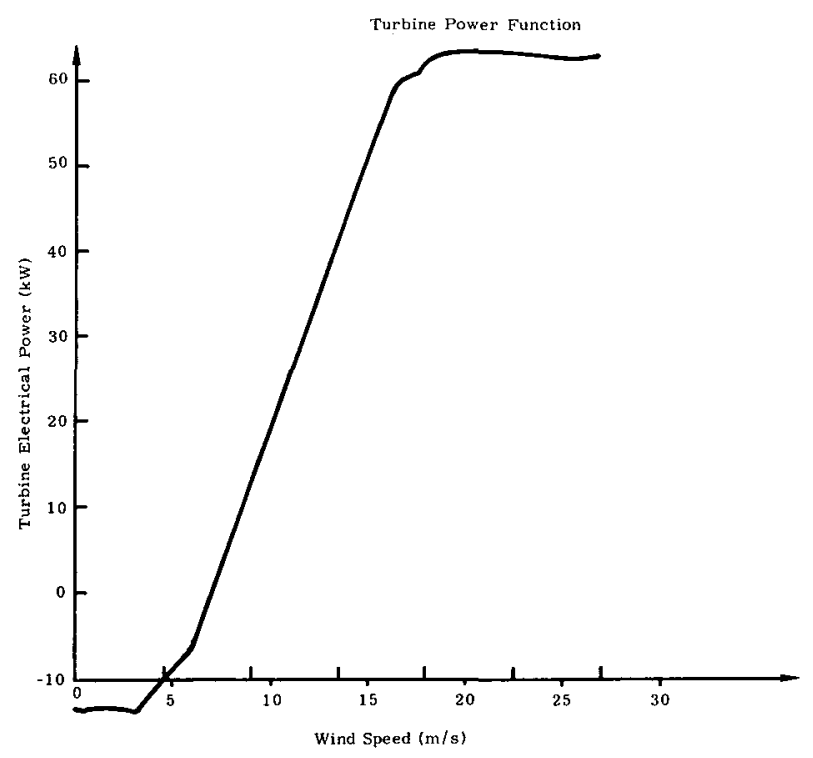

Figure 1. Bins Data for 17-m VAWT 


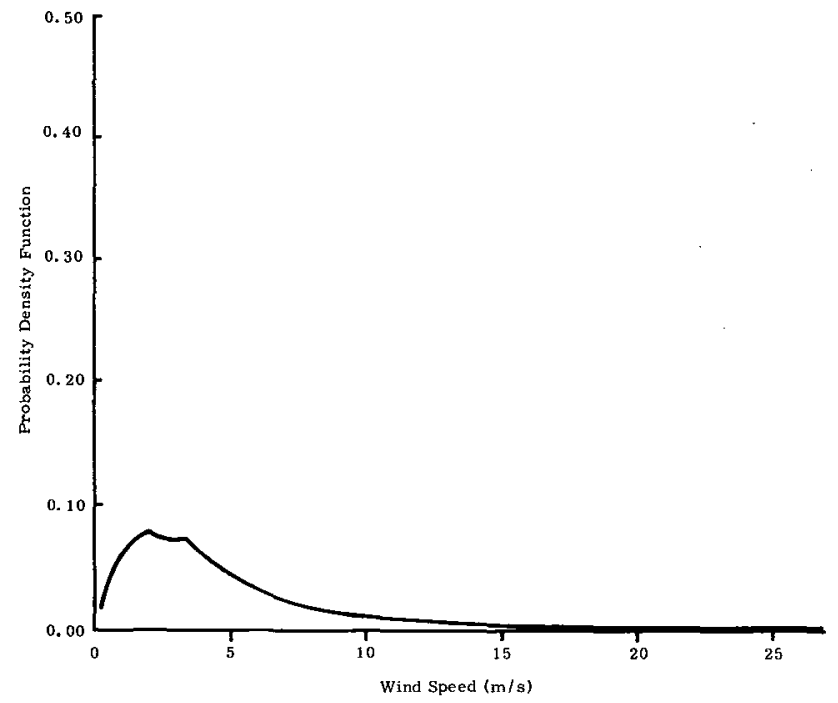

Figure 2. Probability Density Function of Windspeed

The overall energy output that is computed for a particular control algorithm depends on when and how long the turbine runs, as well as the number of starts. The energy consumed by each start is added up, and that sum is subtracted from the calculated energy produced when the turbine is running. For the Sandia/DOE 17-m VAWT, each start consumes approximately $0.6 \mathrm{kWh}$.

The output of the automatic control simulator is given as an algorithm efficiency as well as by the number of starts occurring over the duration of the wind data. The notion of algorithm efficiency* will be given precise meaning following the preliminary notion of the energy available to a turbine-site pair.

\section{Energy Available}

The energy available to a turbine-site pair over the time period, $T$, is calculated as follows:

$E_{T}=T \int_{v_{0}}^{c s}$ power $(v) \cdot p(v) d v$,

where power (v) is the turbine EPC or the average power produced by the turbine at windspeed, $v ; p(v)$ is the windspeed probability density function (PDF) over the time interval, $T$; and $v_{0}$ is the cut-in windspeed.

Power $(\mathrm{v})<0$ for $\mathrm{v}<\mathrm{v}_{\mathrm{o}}$, and

Power $(v) \geq 0$ for $v \geq v_{\mathrm{o}}$.

* The algorithm efficiency of an automatic control system for a turbine-site pair over a test period is that proportion of energy produced by the turbine-site pair, operating under algorithm control, to that of the energy available over the test period.
In practice, the EPC and the PDF for an actual turbine and site are given as a finite set of values, in which case

$E_{T}=T \cdot \sum_{\text {Power }>0}$ Power $\left(v_{i}\right) \cdot p\left(v_{i}\right)$

The energy available then represents the ideal maximum energy that could be produced by a turbine-site pair.

\section{Algorithms Tested}

Five different algorithms have been tested by the automatic control simulator in parameter studies:

- Discrete windspeed

- Moving windspeed

- Moving power

- Discrete, double-power

- Canadian coasting

The first four have two parameters that are adjusted to find the optimum operating values:

- Cut-in/cut-off threshold - The minimum value of average windspeed or average power that is required to start or stop a turbine at low windspeed by a decision loop of a control algorithm

- Test window - The duration of the test period over which the average windspeed or power is calculated for comparison with the cut-in/cutoff threshold

\section{Discrete Windspeed Algorithm}

A windspeed average is calculated and tested against the cut-in/-off threshold at the end of each test window. If the turbine is parked and the average is greater than the cut-in threshold, the turbine is started. If the turbine is operating and the average is less than the cut-off threshold, the turbine is stopped.

\section{Moving Windspeed Algorithm}

A windspeed average is calculated and tested against the cut-in/-off threshold over the test window after each windspeed reading. After a start or stop, a 60 -second blind period is introduced to simulate an actual start or stop. The cut-in algorithm actually used follows:

$$
\begin{aligned}
& \text { Initially, } \mathrm{IC} 1=1, \\
& \mathrm{~T}=\text { test window } \\
& \mathrm{NPT}=\text { number of sample points in } \mathrm{T}
\end{aligned}
$$




$$
\begin{aligned}
& \text { CIT }=\text { cut in threshold } \\
& \text { WSSUM }=0 \\
& \text { ARRAY }(I)=0, I=1, N P T \\
& \text { WSR }=\text { current windspeed reading }
\end{aligned}
$$

with these values,

$$
\begin{array}{ll}
10 & \text { START } \\
\text { READ WSR } \\
\text { IC }=\text { IC } 1 \\
\text { IC1 }=\text { IC } 1+1 \\
\text { IF }(\text { IC1.GT.NPT) IC } 1=1 \\
\text { WSSUM }=\text { WSSUM }+ \text { WSR } \\
\text { WSAUG }=\text { WSSUM } / \mathrm{T} \\
\text { WSSUM }=\text { WSSUM }- \text { ARRAY (IC1) } \\
\text { ARRAY (IC) }=\text { WSR } \\
\text { IF (WSAUG.GE.CIT) START } \\
\text { Continue to } 10 .
\end{array}
$$

\section{Moving Power Algorithm}

The average power is calculated from the poweras-a-function-of-windspeed table of the EPC and tested against the cut-in/-off threshold over the test window after each windspeed reading. After a start or stop, a 60-second blind period is introduced to simulate an actual start or stop. The cut-in algorithm actually used follows:

Initially, $\mathrm{IC} 1=1$

$$
\begin{aligned}
& \mathrm{T}=\text { test window } \\
& \mathrm{NPT}=\text { number of sample points in } \mathrm{T} \\
& \mathrm{CIT}=\text { cut in threshold } \\
& \text { PSUM }=0 \\
& \text { ARRAY }(\mathrm{I})=0 \quad \mathrm{I}=1, \mathrm{NPT} \\
& \text { IWS }=\text { integer nearest the current wind- } \\
& \text { speed ready } \\
& \Delta \mathrm{t}=\text { sample period }
\end{aligned}
$$

with these values,

$$
10 \begin{array}{ll}
\text { START } \\
\text { READ IWS } \\
\text { PR }=\text { POWER (IWS) }{ }^{*} \Delta t \\
\text { IC }=\text { IC } 1 \\
\text { IC1 }=\text { IC } 1+1 \\
\text { IF }(\text { ICI.GT.NPT) IC1 }=1 \\
\text { PSUM }=\text { PSUM }+ \text { PR } \\
\text { PAUG }=\text { PSUM } / \mathrm{T} \\
\text { PSUM }=\text { PSUM }- \text { ARRAY (IC1) } \\
\text { ARRAY (IC) }=\text { PR } \\
\text { IF (PAUG.GE.CIT) START } \\
\text { Continue to } 10 .
\end{array}
$$

\section{Discrete, Double Power Algorithm}

At the end of each test length, two power averages are calculated, one for the average over the entire test window and the other for the last one-tenth of the test window. For a start to occur both values must be greater than the cut-in threshold. Stops are based on a test of the average power over the entire test window.

\section{Canadian Coasting Algorithm}

Certain Canadian VAWT systems have used a semi-mechanical control system with an overruning clutch on the high-speed shaft to permit the rotor to coast when it is turning below the synchronous speed. This system simplifies the cut-off conditionto-rad/s measurements, and could conceivably reduce motoring losses in low winds.

From a cold stop, an algorithm other than the Canadian coasting one is used to decide if a start should be initiated by a motor that takes the turbine to some fraction of the synchronous rotational speed. The turbine is then allowed to coast either until synchronous speed is reached, at which time the generator engages, or until 5 minutes have elapsed and the turbine falls below a cut-off threshold rotational speed. If syncronization is reached, when torque at the high-speed shaft later becomes negative, the generator disengages and the turbin begins coasting again. Whenever the rotor is coasting, the generator is assumed to motor without shaft load at synchronous speed. Windage losses in the generator are accumulated during coasting periods. The only parameter is the cut-off threshold rotational speed.

The turbine rotational speed during free coasting in a varying windspeed is given by the differential equation

$\frac{d w}{d t}=\frac{T_{A}-T_{f}}{I}$,

where

$\mathrm{w}=$ rotational speed

$T_{\mathrm{f}}=$ rotor friction torque

$I=$ rotor inertia

$T_{A}=$ aerodynamic torque as a function of windspeed:

$\mathrm{T}_{\mathrm{A}}=\frac{1}{2} \rho \mathrm{AV} \mathrm{V}^{3}\left[\frac{\mathrm{RW}}{\mathrm{V}}\right]^{3} \mathrm{~K}_{\mathrm{p}}(\mathrm{v})$

$\mathrm{K}_{\mathrm{p}}(\mathrm{v})=$ power coefficient tabulated from 17-m Bins data.

We assume that, the $K_{p}$, when plotted against the windspeed data, does not vary with rotational speed, which is accurate over the small range of rotational speeds of interest.

Figure 3 is the logic flow chart used to simulate the turbine $\mathrm{rad} / \mathrm{s}$ and energy output. 


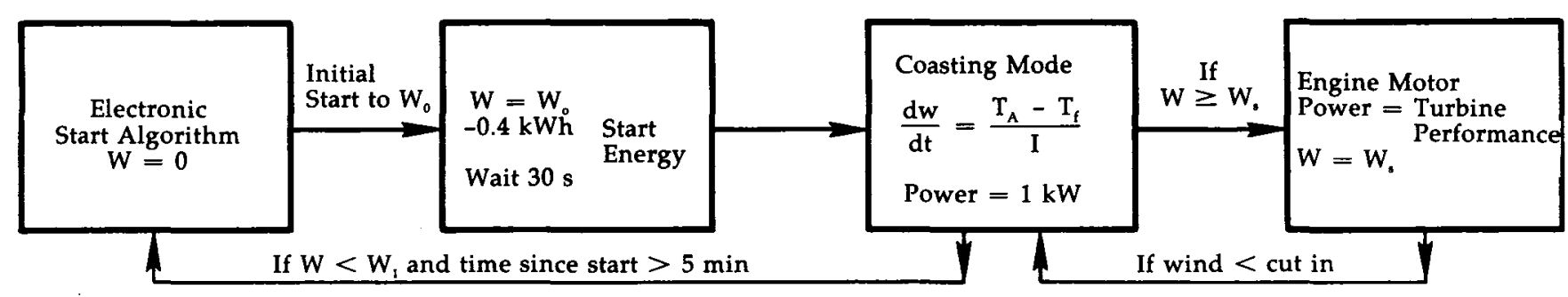

$$
\text { Notes: } \begin{array}{ll}
W_{0}=\text { initial rotor rotational speed } \\
W_{s}=\text { syncronus rotor rotational speed } \\
W_{1}=\text { cut-off threshold rotational speed } \\
W^{\prime}=\text { current rotational speed }
\end{array}
$$

Figure 3. Logic Flow Chart; Turbine Rad/s and Energy Output

\section{Results of Parameter Studies}

The results of the computer runs for parameters of the five algorithms are plotted in Figures 4 through 8 . The maximum curves from each algorithm are then plotted together for easy comparison (Figure 9). The following points become evident from the figures:

- For each algorithm, parameters can be chosen that maximize the algorithm's efficiency and miminize its coasting time and number of starts

- The algorithms can be ranked in the order of their maximum efficiency:

-Canadian coasting: $93.7 \%$

-moving power: $93.4 \%$

-discrete, double-power: $92.8 \%$

-discrete windspeed: $92.3 \%$

-moving windspeed: $91.6 \%$

- Badly chosen parameters, particularly the test window, greatly reduce the efficiency of an algorithm
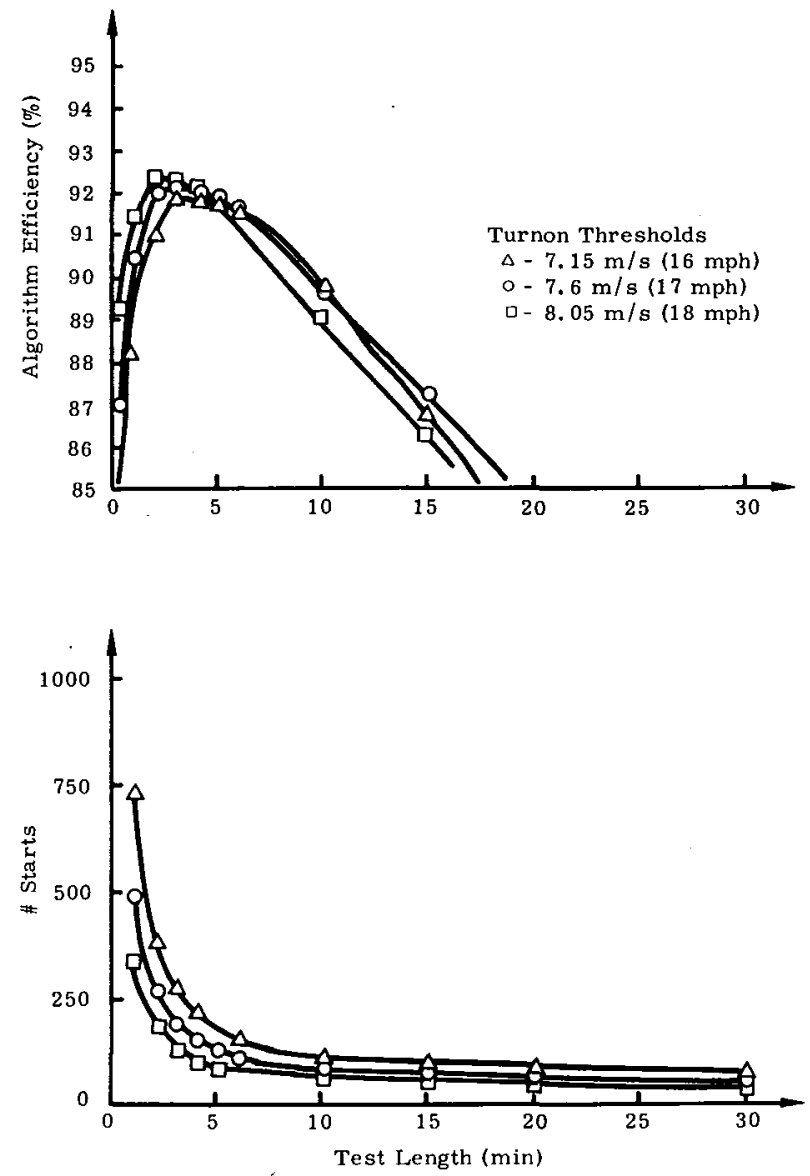

Figure 4. Algorithm \#1 - Discrete Windspeed Averages and Number of Starts 

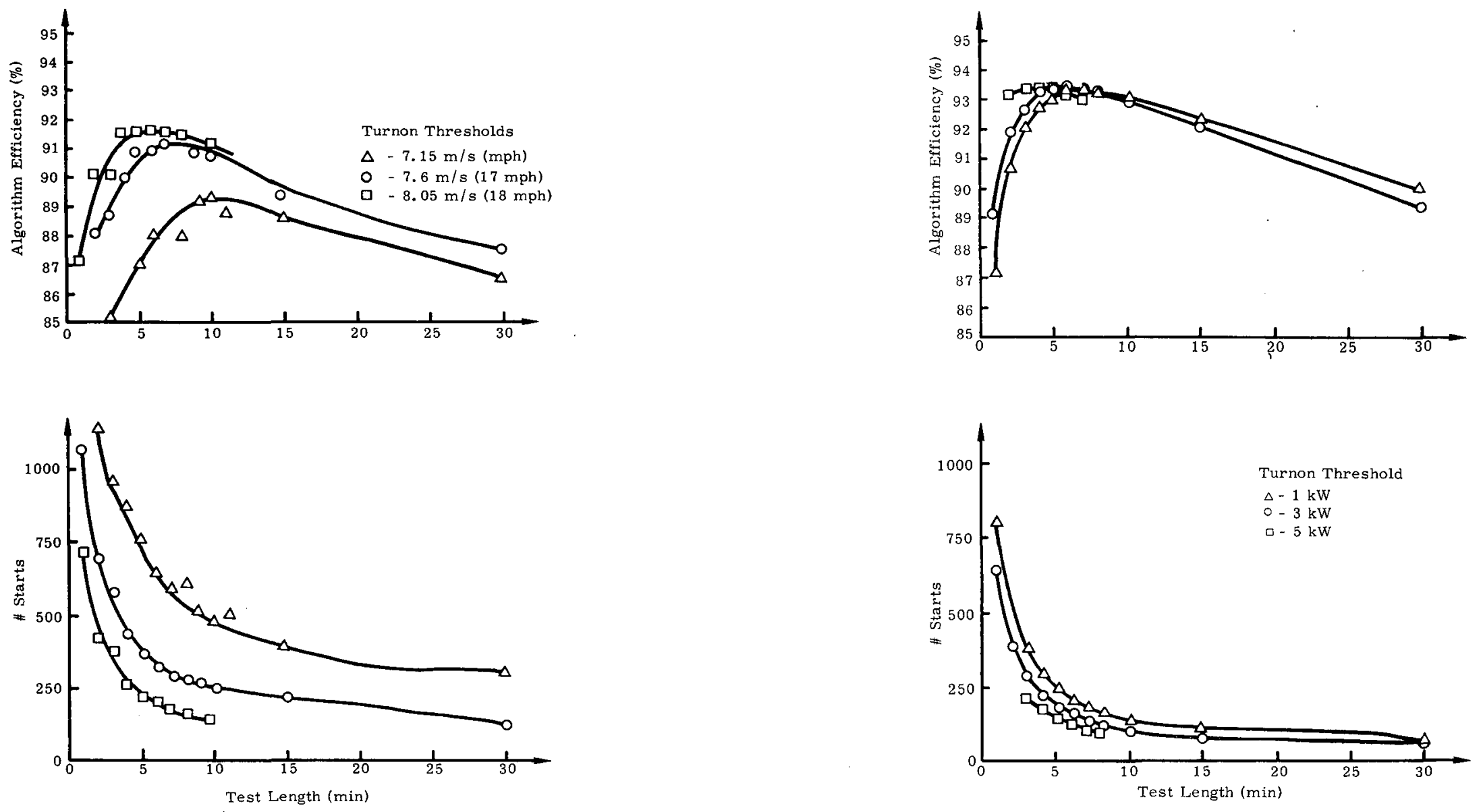

Figure 5. Algorithm \#2 - Moving Windspeed Averages and

Figure 6. Algorithm \#3 - Moving Power Averages and Number of Starts 

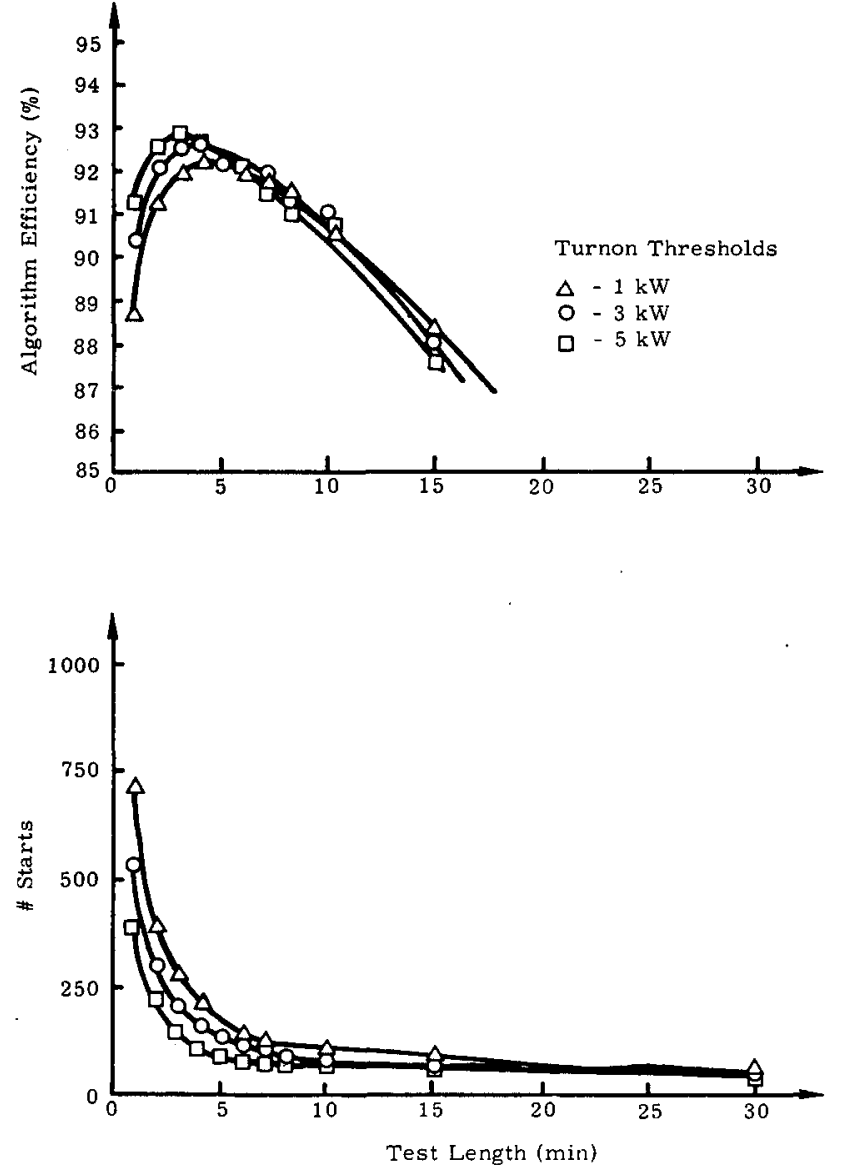

Figure 7. Algorithm \#4 - Discrete, Double Power Test and Number of Starts
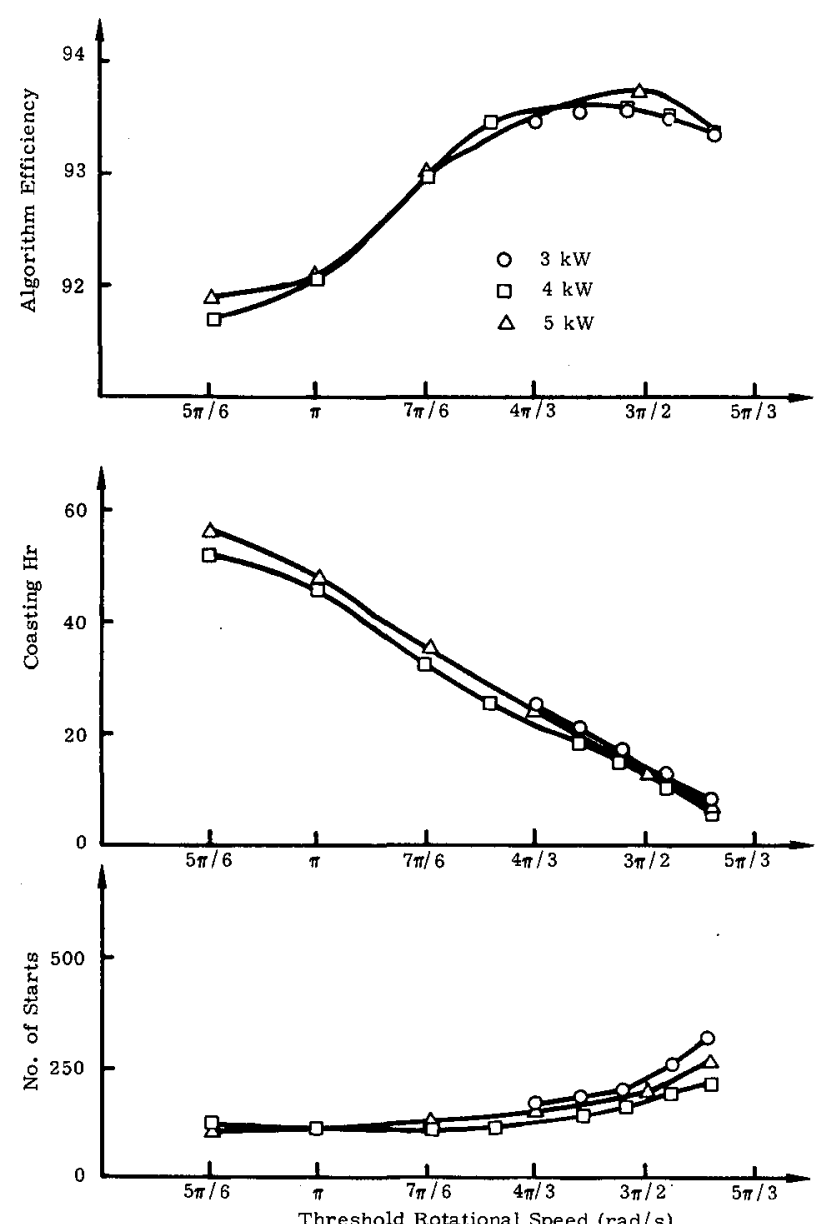

Figure 8. Canadian Coasting Algorithm, Duration of Coasting, and Number of Starts 


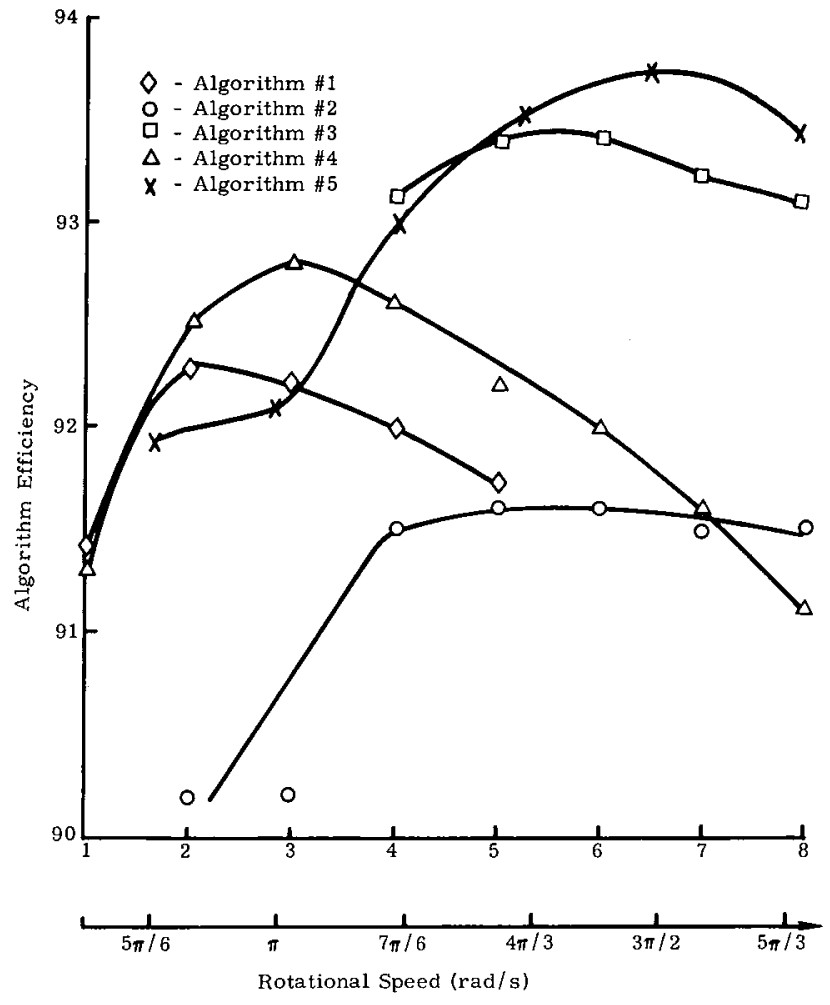

Figure 9. Comparison of the Best Curves of the Five Algorithms

\section{Applications to VAWT Economics}

The study on algorithm control can be used to maximize energy production, once a particular turbine-site pair has been selected. However, if a turbine is badly matched to a site, the maximum efficiency of an algorithm may be as low as $72 \%$. Therefore, control algorithms can affect the economics of wind energy production.

To use control algorithms in wind energy economics, we must determine if the maximum efficiency depends on the probability distribution function (PDF) of local windspeed suitably combined with the turbine EPC. Since the PDF and the EPC are functions of windspeed, it is natural to use both to construct the energy distribution function (EDF) which, at any windspeed, gives the fraction of the annual energy produced by the machine at that particular windspeed. Since the EDF is the product of the PDF and the EPC, we should concentrate on determining how much the maximum algorithm efficiency depends on the EDF.

The first time the five algorithms were tested, we used the EPC from the Sandia/DOE 17-m VAWT (determined from experiments based on the Bins method) and the windspeed time series recorded at the same test site. We could find no general relationship between the maximum algorithm efficiency and the EDF in the data from only one turbine-site pair. Therefore, we expanded the data base to include several more turbine EPCs and another set of windspeed time series that consisted of data recorded from October 1, 1976 to November 26, 1977 by the National Severe Storm Laboratory in Oklahoma City, most at a sample rate of $0.1 \mathrm{~Hz}$. This series, transcribed to 9-track magnetic tape, includes windspeed and direction; temperature; vertical velocity at seven elevations; air pressure; wet-bulb temperature; pyranometer, and rain gauge readings from selected elevations. We used the windspeed data recorded at $26 \mathrm{~m}$ for the model because this elevation most closely matches the equatorial elevation of the VAWTs in which we are interested. The PDF of the series comes close to the Rayleigh distribution with a mean windspeed of $4.65 \mathrm{~m} / \mathrm{s}(10.4 \mathrm{mi} / \mathrm{hr}$ ) (Figure 10).

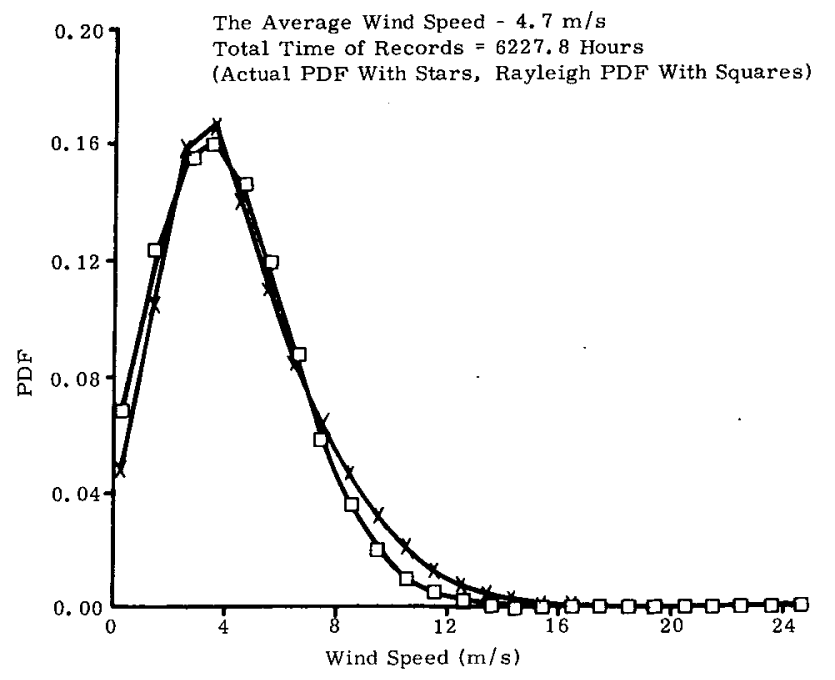

Figure 10. Comparison of WKY Tower PDF With Rayleight PDF

Besides the EPC of the Sandia/DOE VAWT, we have used two other curves:

- An EPC generated by the computer code PAREP2 for a 17-m VAWT turning at 2.6, 3.14, $3.66,4.19$, and $4.71 \mathrm{rad} / \mathrm{s}(25,30,35,40$, and 45 rpm)

- An EPC from a one-parameter family of piecewise linear curves defined by the function

$$
P(V)=\left\{\begin{array}{c}
-6 k W \text { for } 0 \leq V \leq V_{0}-2.2 \\
2.7^{*}\left(V-V_{0}\right) \text { for } V_{0}-2.2 \leq V \leq 3^{*} V_{0}-6.6 \\
5.4^{*} V_{0}-18 \text { for } 3^{*} V_{0}-6.6 \leq V
\end{array}\right.
$$


where $V_{O}$ is the cut in windspeed, satisfying $P\left(V_{o}\right)=0.0$; this EPC gives wide variation in turbine characteristics that depend on one parameter.

Subsequently, we conducted tests with the automatic control simulator, using only the movingpower algorithm because it had clearly outperformed the other three, purely electronic, algorithms and performed almost as well as the coasting algorithm.

Dependency of the maximum algorithm efficiency on the EDF may take many forms. After we found the maximum efficiencies for several cases by running many tests of the automatic control simulator corresponding to different data sets, we plotted the maximum algorithm efficiency against various properties of the EDFs. Two clear relationships emerged, either of which may be used to determine the approximate maximum algorithm efficiency corresponding to a given EDF. The first (Figure 11) is between the maximum algorithm efficiency and the slope of the EDF at the cut-in windspeed, $E_{0}$. The second (Figure 12) is between the maximum algorithm efficiency and the ratio

$R=\frac{V_{m}-V_{o}}{V_{o}}$,

where $V_{m}$ is the windspeed at the maximum EDF and $V_{o}$ is the cut-in windspeed.

In Figures 11 and 12, we see that the maximum algorithm efficiency may be given as a function of either $E_{o}$ or $R$. This functional relationship may be used to select an economical VAWT for a given site or, more basically, to determine if a VAWT is badly suited, so far as controlling it is concerned, for a turbine site. For example, the Sandia 17-m VAWT would be ill-suited for Oklahoma City, where it would produce a maximum algorithm efficiency of $72 \%$.

\section{References}

$1_{R}$. Akins, Performance Evaluation of Wind Energy Conversion Systems Using the Method of Bins - Current Status, SAND77-1375 (Albuquerque: Sandia Laboratories, March 1978).

${ }^{2} \mathrm{~T}$. Leonard, A User's Manual for the Computer Code PAREP, SAND79-0431 (Albuquerque: Sandia National Laboratories, April 1979).

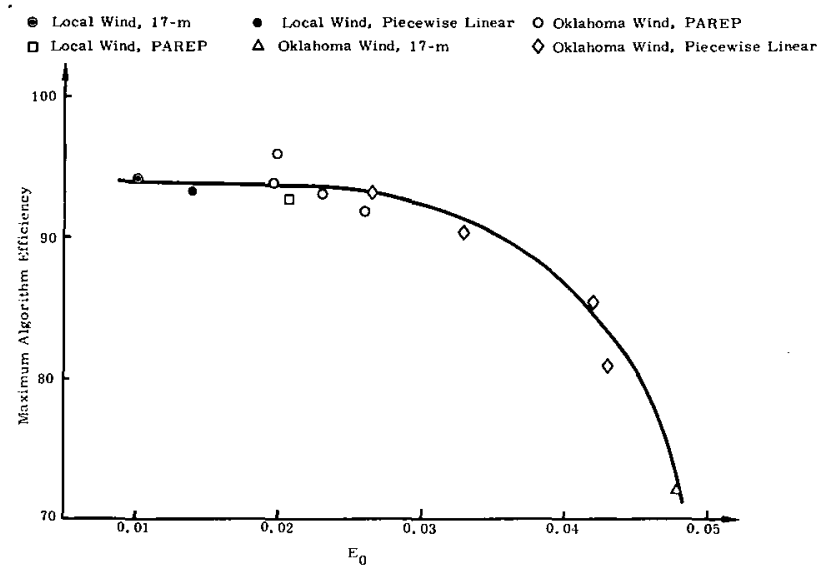

Figure 11. Maximum Algorithm Efficiency vs $E_{O}$

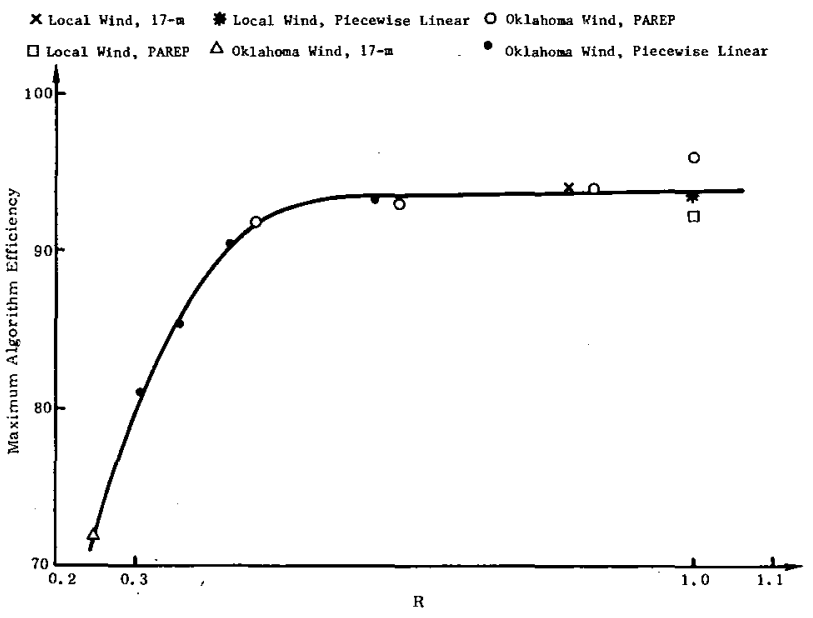

Figure 12. Maximum Algorithm Efficiency vs $R$ 


\section{DISTRIBUTION:}

Wichita State University (2)

Aero Engineering Department

Wichita, KS 67208

Attn: M. Snyder

W. Wentz

Virginia Polytechnic Institute and State University Department of Engineering Science and Mechanics Blacksburg, VA 24060

Attn: R.E. Akins, Assistant Professor

Aluminum Company of America (5)

Alcoa Laboratories

Alcoa Technical Center

Alcoa Center, PA 15069

Attn: D. K. Ai

A. G. Craig

J. T. Huang

J. R. Jombock

P. N. Vosburgh

Dynergy Corporation

P.O. Box 428

1269 Union Avenue

Laconia, NH 03246

Attn: R. B. Allen, General Manager

American Wind Energy Association

1609 Connecticut Avenue NW

Washington, DC 20009

South Dakota School of Mines and Technology

Department of Mechanical Engineering

Rapid City, SD 57701

Attn: E. E. Anderson

University of Vermont

318 Millis Hall

Burlington, VT 05405

Attn: S. Anderson

DOE/Office of Commercialization

20 Massachusetts Avenue NW

Mail Station 2221C

Washington, DC 20585

Attn: G. T. Ankrum

McDonnell-Douglas Aircraft Corporation

P.O. Box 516

Department 341, Building 32/2

St. Louis, MO 63166

Attn: R. Brulle
Stanford University

Department of Aeronautics and

Astronautics Mechanical Engineering

Stanford, CA 94305

Attn: H. Ashley

Consolidated Edison Company of New York, Inc., 4 Irving Place

New York, NY 10003

Attn: K. Austin

Hayes, Seay, Mattern, and Mattern

1315 Franklin Road SW

Roanoke, VA 24016

Attn: B. H. Barksdale, Jr.

University of California

Institute of Geophysics and Planetary Physics

Riverside, CA 92521

Attn: P. J. Baum

Washington State University

Department of Electrical Engineering

College of Engineering

Pullman, WA 99163

Attn: F. K. Bechtel

Arizona State University

Solar Energy Collection

University Library

Tempe, AZ 85281

Attn: M. E. Beecher

Leon Bjervig

Civilingenior, MCIF

"Osterbyhus", 6990 Ulfborg

DK6990

DENMARK

University of Oklahoma

Aero Engineering Department

Norman, OK 73069

Attn: K. Bergey

Wind Energy Systems

Route 1, Box 93-A

Oskaloosa, KS 66066

Attn: S. Blake

Tumac Industries

650 Ford Street

Colorado Springs, CO 80915

Attn: G. B. Curtis 


\section{DISTRIBUTION: (cont)}

University of Sherbrooke

Faculty of Applied Science

Sherbrooke, Quebec

CANADA J1K 2R1

Attn: R. Camerero

CERCEM (2)

49 Rue du Commandant Rolland

93350 Le Bourget

FRANCE

Attn: G. Darrieus

J. Delassus

University of Auckland

School of Engineering

Private Bag

Auckland, NEW ZEALAND

Attn: V. A. L. Chasteau, Professor

McDonnell Aircraft Corporation

P.O Box 516

Department 337, Building 32

St. Louis, MO 63166

Attn: H. T. Clark

USDA, Agricultural Research Service

Southwest Great Plains Research Center

Bushland, TX 79012

Attn: R. N. Clark

State Consumer Protection Board

Consumer Outreach Coordinator

State of New York

Executive Department

99 Washington Avenue

Albany, NY 12210

Attn: J. D. Cohen

University of Massachusetts

Mechanical and Aerospace Engineering Department

Amherst, MA 01003

Attn: D. E. Cromack, Associate Professor

DOE/ALO (2)

Albuquerque, NM 87115

Attn: G. P. Tennyson
DOE Headquarters/WESD (20)

600 E Street NW

Washington, DC 20545

Attn: D. F. Ancona

C. E. Aspliden

L. V. Divone

W. C. Reddick

Southern Illinois University

School of Engineering

Carbondale, IL 62901

Attn: C. W. Dodd

Kaiser Aluminum and Chemical Sales, Inc. 6177 Sunol Blvd.

P.O. Box 877

Pleasanton, CA 94566

Attn: D. D. Doerr

Dominion Aluminum Fabricating Ltd. (2)

3570 Hawkestone Road

Mississauga, Ontario

CANADA L5C 2U8

Attn: L. Schienbein

C. Wood

Hamilton Standard

1730 NASA Boulevard

Room 207

Houston, TX 77058

Attn: D. P. Dougan

Nederlands Energy Research Foundation (E.C.N.)

Physics Department

Westerduinweg 3 Patten (nh)

THE NETHERLANDS

Attn: J. B. Dragt

Battelle-Pacific Northwest Laboratory (2)

P.O. Box 999

Richland, WA 99352

Attn: C. E. Elderkin

A. Miller

The Mitre Corporation

1820 Dolley Madison Blvd.

McLean, VA 22102

Attn: F. R. Eldridge, Jr. 


\section{DISTRIBUTION: (cont)}

Electric Power Research Institute

3412 Hillview Avenue

Palo Alto, CA 94304

Attn: E. Demeo

The Resources Agency

Department of Water Resources

Energy Division

1416 9th Street

P.O. Box 388

Sacremento, CA 95802

Attn: R. G. Ferreira, Chief

New England Geosystems

P.O. Box 128

East Derry, NH 03041

Attn: D. R. Finley

University of Colorado

Department of Aerospace Engineering Sciences

Boulder, CO 80309

Attn: J. D. Fock, Jr.

Public Service Company of New Hampshire 1000 Elm Street

Manchester, NH 03105

Attn: L. C. Frederick

Universite Laval-Quebec

Mechanical Engineering Department

Faculty of Sciences and Engineering

CANADA G1K 7P4

Attn: H. Gerardin

Amarillo College

Amarillo, TX 79100

Attn: E. Gilmore

Wind Power Digest

P.O. Box 539

Harrisburg, PA 17108

Attn: P. Gipe

University College of Swansea

Department of Mechanical Engineering

Singleton Park

Swansea SA2 8PP

UNITED KINGDOM

Attn: R. T. Griffiths
Richard Haddad

101 Arizona

P.O. Box 530

El Paso, TX 79944

Kaiser Aluminum and Chemical Sales, Inc. 14200 Cottage Grove Avenue

Dolton, IL 60419

Attn: A. A. Hagman

Project Department

Electricity Supply

18 St. Stephen's Green

Dublin 2, IRELAND

Attn: M. L. Hally, Section Manager

Massachusetts Institute of Technology

77 Massachusetts Avenue

Cambridge, MA 02139

Attn: N. D. Ham, Professor

Wind Engineering Corporation

Airport Industrial Area

Box 5936

Lubbock, TX 79415

Attn: C. F. Harris

Massachusetts Institute of Technology

Aero/Astro Department

Cambridge, MA 02139

Attn: W. L. Harris

Rockwell International (2)

Rocky Flats Plant

P.O. Box 464

Golden, CO 80401

Attn: T. Healy

Helion

P.O. Box 4301

Sylmar, CA 91342

AMBIO

KVA

Fack, S-10405

Stockholm

SWEDEN

Attn: D. Hinrichsen, Associate Editor 


\section{DISTRIBUTION: (cont)}

Sven Hugosson

Box 21048

S. 10031 Stockholm 21

SWEDEN

Ben-Gurion University of the Negev Department of Mechanical Engineering Beer-Sheva, ISRAEL

Attn: O. Igra

Indian Oil Corporation, Ltd.

Marketing Division

254-C, Dr. Annie Besant Road

Prabhadevi, Bombay-400025

INDIA

JBF Scientific Corporation

2 Jewel Drive

Wilmington, MA 01887

Attn: E. E. Johanson

Kansas State University

Electrical Engineering Department

Manhattan, KS 66506

Attn: G. L. Johnson, P.E.

B. O. Kaddy, Jr.

Box 353

31 Union Street

Hillsboro, NH 03244

Kaman Aerospace Corporation

Old Windsor Road

Bloomfield, CT 06002

Attn: W. Batesol

R. L. Katzenberg

2820 Upton St. NW

Washington, DC 20008

The College of Trades and Technology

P.O. Box 1693

Prince Philip Drive

St. John's Newfoundland

CANADA A1C 5P7

Attn: R. E. Kelland

S. King

Natural Power, Inc.

New Boston, NH 03070
Aeroenvironment, Inc.

660 South Arroyo Parkway

Pasadena, CA 91105

Attn: P.B.S. Lissaman

Samuel H. Kohler

272 Old Delp Road

Lancaster, PA 17602

Michigan State University

Division of Engineering Research

East Lansing, MI 48824

Attn: O. Krauss

Carol Lamb

2584 East Geddes Avenue

Littleton, CO 80122

Lawrence Livermore Laboratory

P.O. Box 808 L-340

Livermore, CA 94550

Attn: D. W. Dorn

Public Service Company of New Mexico

P.O. Box 2267

Albuquerque, NM 87103

Attn: M. Lechner

Kalman Nagy Lehoczky

Cort Adelers GT.30

Oslo 2

NORWAY

Reynolds Metals Company

Mill Products Division

6601 West Broad Street

Richmond, VA 23261

Attn: G. E. Lennox, Industry Director

State Energy Commission

Research and Development Divison

1111 Howe Avenue

Sacramento, CA 95825

Attn: J. Lerner

Department of Agriculture

US Agriculture Research Center

Building 303

Beltsville, MD 20705

Attn: L. Liljidahl 


\section{DISTRIBUTION: (cont)}

Larry Kinnett

P.O. Box 6593

Santa Barbara, CA 93111

Ford Motor Company

Environmental Research and Energy Planning Director

Environmental and Safety Engineering Staff

The American Road

Dearborn, MI 48121

Attn: J. R. Moroni

Dardalen Associates

15110 Frederick Road

Woodbine, MD 21797

Attn: F. Matanzo

Toray Industries, Inc.

Composite Materials Laboratory

Pioneering R\&D Laboratories

Sonoyama, Otsu, Shiga

JAPAN 520

Attn: H. S. Matsuda, Manager

Tumac Industries, Inc.

650 Ford St.

Colorado Springs, CO 80915

Attn: J. R. McConnell

Kaman Sciences Corporation

P.O. Box 7463

Colorado Springs, CO 80933

Attn: J. Meiggs

Colorado State University

Department of Civil Engineering

Fort Collins, CO 80521

Attn: R. N. Meroney

Department of Economic Planning and Development

Barrett Building

Cheyenne, WY 82002

Attn: G. N. Monsson

NASA Lewis Research Center (4)

21000 Brookpark Road

Cleveland, OH 44135

Attn: J. Savino

R. L. Thomas

W. Robbins

K. Kaza
Olle Ljungstrom

FFA, The Aeronautical Research Institute Box 11021

S-16111 Bromma

SWEDEN

US Turbine Corporation

Olde Courthouse Building

Canfield, Oh 44406

Attn: T. H. Logan

Siltex

7 Capitol Drive

Moonachie, NJ 07074

Attn: J. B. Longendyck

Los Alamos National Laboratory

P.O. Box 1663

Los Alamos, NM 87544

Attn: J. D. Balcomb, Q-DO-T

Beatrice de Saint Louvent

Establissement d'Etudes et de Recherches Meteorologigues

77 Rue de Serves

92106 Boulogne-Billancourt Cedex

FRANCE

PRC Energy Analysis Co.

7600 Old Springhouse Rd.

McLean, VA 22101

Attn: E. L. Luther, Senior Associate

L. H. J. Maile

48 York Mills Rd.

Willowdale, Ontario

CANADA M2P 1B4

Motorola, Inc.

G.E.D.

Mail Drop 1429

8201 E. McDowell Rd.

P.O. Box 1417

Scottsdale, AZ 85252

Attn: E. L. Markowski

West Texas State University

Department of Physics

P.O. Box 248

Canyon, TX 79016

Attn: V. Nelson 


\section{DISTRIBUTION: (cont)}

The Power Company, Inc.

P.O. Box 221

Genesee Depot, WI 53217

Attn: A. A. Nedd

Natural Power, Inc.

New Boston, NH 03070

Attn: L. Nichols

Ronald Nousain

P.O. Box 111

Rome 1132

Los Angeles, CA 90051

Oklahoma State University (2)

Stillwater, OK 76074

Attn: W. L. Hughes, EE Department

D. K. McLaughlin, ME Department

Oregon State University (2)

Corvallis, OR 97331

Attn: R. E. Wilson, ME Department

R. W. Thresher, ME Department

County Commissioner

Precinct 4

City-County Building

El Paso, TX 79901

Attn: P. F. O'Rourke

Dow Chemical USA

Research Center

2800 Mitchell Drive

Walnut Creek, CA 94598

Attn: H. H. Paalman

Flow Industries, Inc.

21414 68th Ave. So.

Kent, WA 98031

Attn: Y. H. Pao, Chairman

Ion Paraschivoiu

IREQ

1800 Montee Ste-Julie

Varennes, Quebec

CANADA JOL 2P0

Northwestern University

Department of Civil Engineering

Evanston, IL 60201

Attn: R. A. Parmalee
Helge Petersen

Riso National Laboratory

DK-4000 Roskilde

DENMARK

National Rural Electric Cooperative Association 1800 Massachusetts Avenue NW

Washington, DC 20036

Attn: W. Prichett, III

Commonwealth Scientific and Industrial Research Organization

Division of Mechanical Engineering

Graham Road, Highett

Victoria, 3190

AUSTRALIA

Attn: B. Rawlings, Chief

The University of Tennessee

Department of Electrical Engineering

Knoxville, TN 37916

Attn: T. W. Reddoch

Atlantic Wind Test Site

P.O. Box 189

Tignish, P.E.I.

COB 2B0 CANADA

Attn: R. G. Richards

Memorial University of Newfoundland Faculty of Engineering and Applied Sciences

St. John's Newfoundland

CANADA A1C 557

Attn: A. Robb

Solarwind Energy Corporation

1163 Pomona Road

Unit A

Corona, CA 91720

Attn: J. R. Rodriguez

Institut fur Leichbau

Technische Hochschule Aachen

Wullnerstrasse 7

GERMANY

Attn: Ing. Hans Ruscheweyh

Iowa State University

Agricultural Engineering, Room 213

Ames, IA 50010

Attn: L. H. Soderholm 


\section{DISTRIBUTION: (cont)}

National Atomic Museum

Albuquerque, NM 87185

Attn: G. Schreiner, Librarian

9 US Department of Energy

P.O. Box 3621

102 NE Holladay

Portland, OR 97208

Attn: D. B. Seely, P.E.

Arnan Seginer

Professor of Aerodynamics

Technion-Israel Institute of Technology

Department of Aeronautical Engineering

Haifa, ISRAEL

Horst Selzer

Dipl.-Phys.

Wehrtechnik und Energieforschung

ERNO-Raumfahrttechnik GmbH

Hunefeldstr. 1-5

Postfach 105909

2800 Bremen 1

GERMANY

Bristol Aerospace Ltd.

Rocket and Space Division

P.O. Box 874

Winnipeg, Manitoba

CANADA R3C $2 S 4$

Attn: H. Sevier

P. N. Shankar

Aerodynamics Division

National Aeronautical Laboratory

Bangalore 560017

INDIA

Kingston Polytechnic

Canbury Park Road

Kingston, Surrey

UNITED KINGDON

Attn: D. Sharpe

Cornell University

Sibley School of Mechanical and

Aerospace Engineering

Ithaca, NY 14853

Attn: D. G. Shepherd
Colorado State University

Ft. Collins, CO 80521

Attn: F. Smith, Mechanical Eng Dept. Head

Kent Smith Instituto Technologico Costa Rica

Apartado 159 Cartago

COSTA RICA

Bent Sorenson

Roskilde University Centery

Energy JGroup, Bldg. 17.2

IMFUFA

P.O. Box 260

DK-400 Roskilde

DENMARK

Southwest Research Institute (2)

P.O. Drawer 28501

San Antonio, TX 78284

Attn: W. L. Donaldson, Senior Vice President R. K. Swanson

Rick Stevenson

Route 2

Box 85

Springfield, MO 65802

Morey/Stjernholm and Associates

1050 Magnolia Street

Colorado Springs, CO 80907

Attn: D. T. Stjernholm, P.E.

Mechanical Design Engineer

G. W. Stricker

130 Merchant St. \#1104

Honolulu, HI 96813

C. J. Swet

Route 4

Box 358

Mt. Airy, MD 21771

Texas Tech University (3)

P.O. Box 4389

Lubbock, TX 79409

Attn: K. C. Mehta, CE Department J. Strickland, ME Department J. Lawrence, ME Department 


\section{DISTRIBUTION: (cont)}

National Research Council

ASEB

2101 Constitution Avenue

Washington, DC 20418

Attn: J. Taylor

NRC-National Aeronautical Establishment (3)

Low Speed Aerodynamics Section

Ottawa 7, Ontario

CANADA K1A OR6

Attn: R. J. Templin

Atari, Inc.

155 Moffett Park Drive

Sunnyvale, CA 94086

Attn: F. Thompson

Aero Propulsion Laboratory

Terrestrial Energy Technology Program Office

Energy Conversion Branch

Aerospace Power Division

Department of the Air Force

Air Force Wright Aeronautical Laboratories (AFSC)

Wright-Patterson Air Force Base, $\mathrm{OH} 45433$

Attn: J. M. Turner, Group Leader

United Engineers and Constructors, Inc.

Advanced Engineering Department

30 South 17th Street

Philadelphia, PA 19101

Attn: A. J. Karalis

University of New Mexico

New Mexico Engineering Research Institute

Campus, P.O. Box 25

Albuquerque, NM 87131

Attn: G. G. Leigh

University of New Mexico (2)

Albuquerque, NM 87106

Attn: K. T. Feldman, Energy Research Center V. Sloglund, ME Department

University of New Mexico

Department of Mathematics

Albuquerque, NM 87106

Attn: A. Stone

University of New Mexico

Physics Department

Albuquerque, NM 87106

Attn: J. D. Finley
Jan Vacek

Eolienne Experimentale

C.P. 279, Cap-aux-Meules

Iles de la Madeleine, Quebec

CANADA

Solar Energy Research Institute

1617 Cole Blvd.

Golden, CO 80401

Attn: I. E. Vas

Otto de Vries

National Aerospace Laboratory

Anthony Fokkerweg 2

Amsterdam 1017

THE NETHERLANDS

West Virginia University

Department of Aero Engineering

1062 Kountz Avenue

Morgantown, WV 26505

Attn: R. Walters

Bonneville Power Administration

P.O. Box 3621

Portland, OR 97225

Attn: E. J. Warchol

ERA Ltd.

Energy and Power Systems

Cleeve Rd.

Leatherhead

Surrey KT22 7SA

ENGLAND

Attn: D. F. Warne, Manager

The Energy Center

Pennine House

4 Osborne Terrace

Newcastle upon Tyne NE2 1NE

UNITED KINGDOM

Attn: G. R. Watson, Project Manager

Watson Bowman Associates, Inc.

1280 Niagara St.

Buffalo, NY 14213

Attn: R. J. Watson

Tulane University

Department of Mechanical Engineering

New Orleans, LA 70018

Attn: R. G. Watts 


\section{DISTRIBUTION: (cont)}

Mississippi State Univeristy

Mechanical Engineering Department Mississippi State, MS 39762

Attn: W. G. Wells, P.E., Associate Professor

University of Alaska

Geophysical Institute

Fairbanks, AK 99701

Attn: T. Wentink, Jr.

West Texas State University

Government Depository Library

Number 613

Canyon, TX 79015

Wind Energy Report

Box 14

102 S. Village Ave.

Rockville Centre, NY 11571

Attn: F. S. Seiler

Wind Program Manager

Wisconsin Division of State Energy

8th Floor

101 South Webster Street

Madison, WI 53702

Central Solar Energy Research Corp.

1200 Sixth Street

328 Executive Plaza

Detroit, MI 48226

Attn: R. E. Wong

1000 G. A. Fowler

1200 L. D. Smith
2525 R. P. Clark

3161 J. E. Mitchell (15)

3161 P. S. Wilson

4533 J. W. Reed

$4700 \mathrm{~J}$. H. Scott

4710 G. E. Brandvold

4715 R. H. Braasch (200)

4715 J. D. Cyrus

4715 R. D. Grover

4715 E. G. Kadlec

4715 P. C. Klimas

4715 M. T. Mattison

4715 R. O. Nellums

4715 W. N. Sullivan

4715 R. A. Watson

4715 D. F. Wolf

4715 M. H. Worstell

5520 T. B. Lane

5523 R. C. Reuter, Jr.

5523 T. G. Carne

5523 D. B. Clauss

5523 D. W. Lobitz

5523 P. S. Veets

5600 D. B. Schuster

5620 M. M. Newsom

5630 R. C. Maydew

5633 R. E. Sheldahl

5634 R. H. Croll

5636 J. K. Cole

5636 D. E. Berg

5636 W. H. Curry

8214 M. A. Pound

3141 L. J. Erickson (5)

3151 W. L. Garner (3)

For: DOE/TIC (Unlimited Release)

DOE/TIC (25)

(J. H. Dalin 3154-3) 